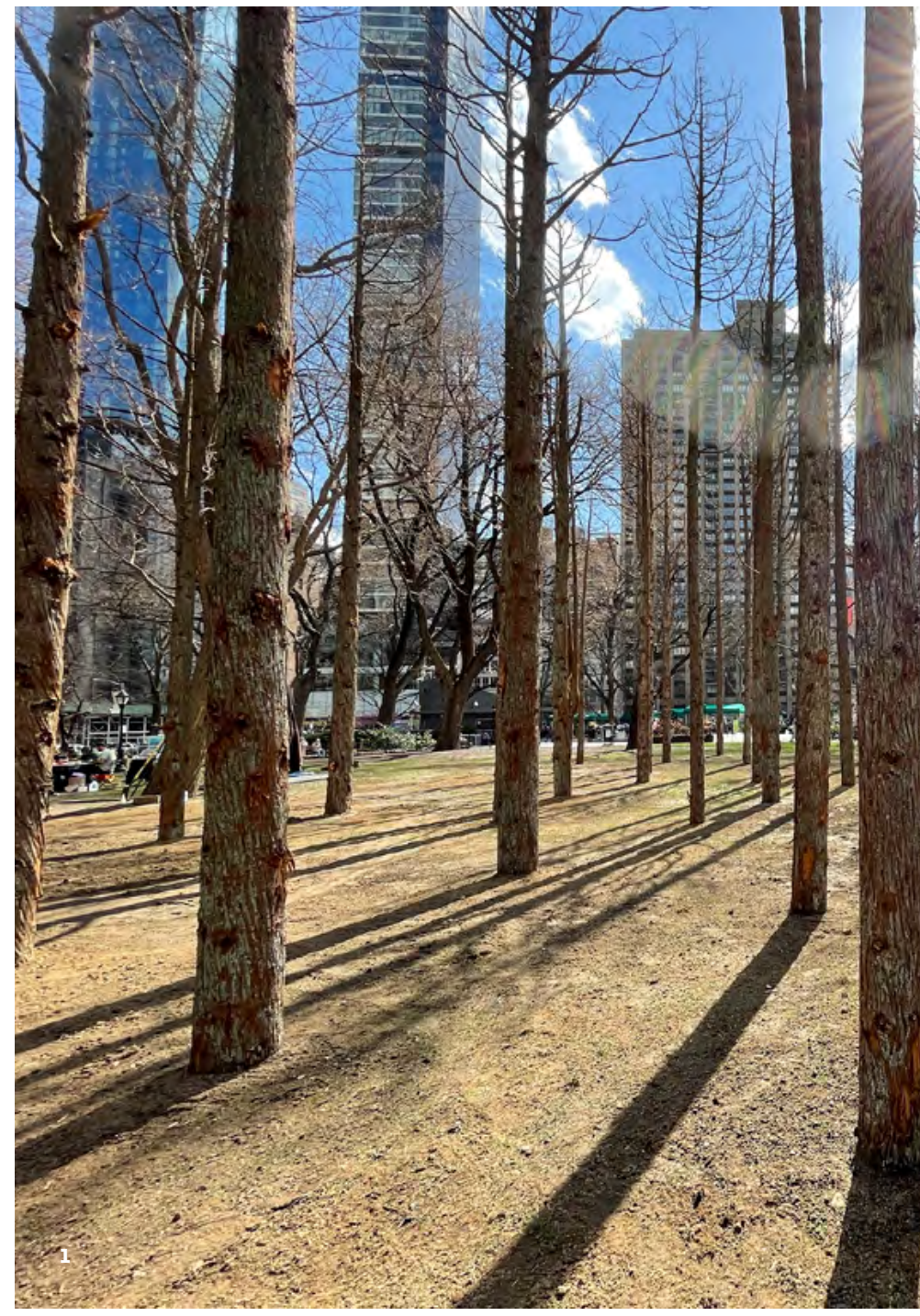

Portafolio / Portfolio
MAYA LIN

New York, 2021

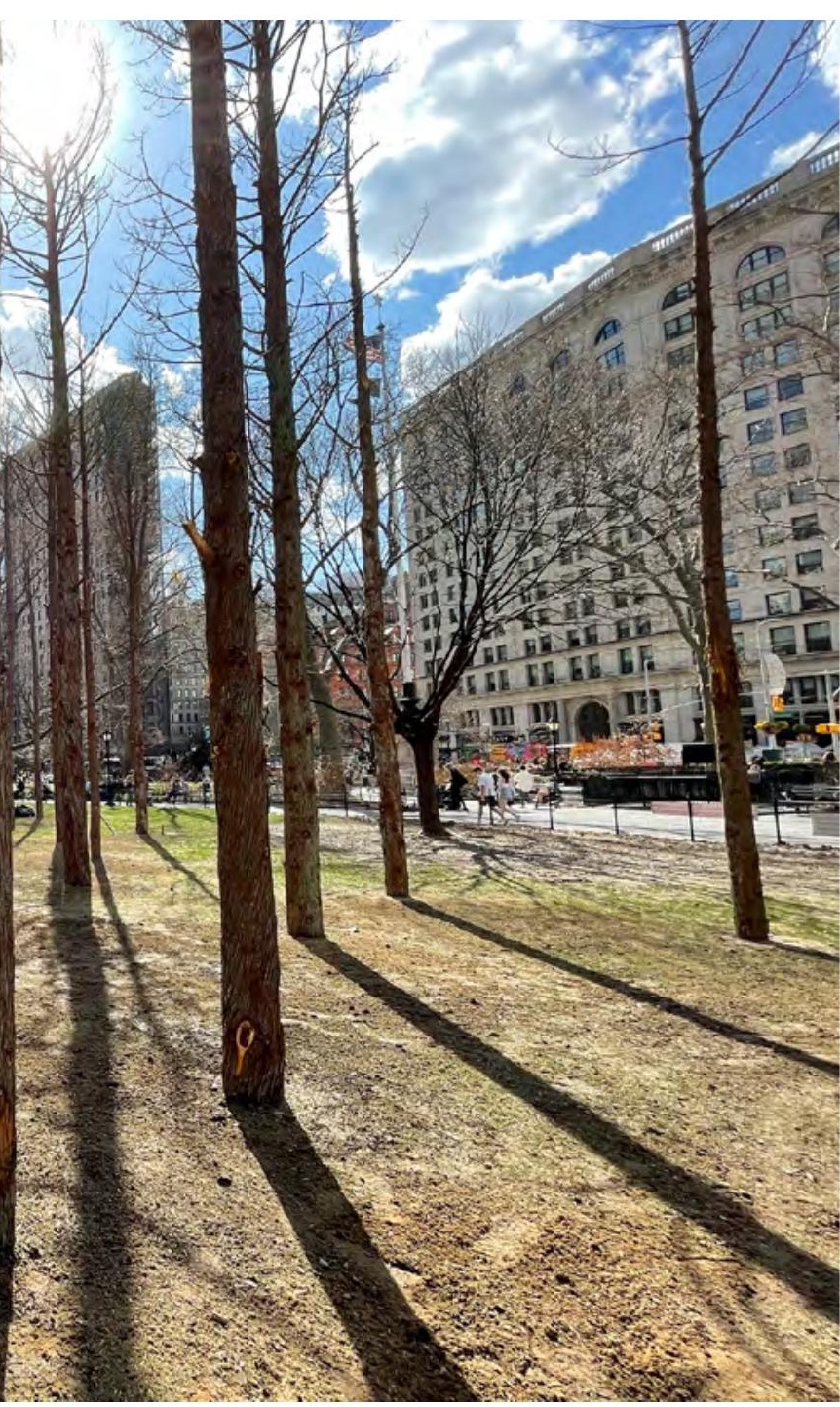

1 Maya Lin. Bosque fantasma / Ghost Forest, 2021

(c) Maya Lin Studio Cortesía de / Courtesy Maya Lin \& Madison Square Park Conservancy

\title{
GHOST FOREST
}

As living things, trees also die. But, since there are no funerals or burials, many trees killed by the various manifestations of climate change remain standing, like corpses that remind us of life's fragility. This installation by Maya Lin brings back those ghosts, a forest of logs without sap or chlorophyll, as a foretaste of the possible apocalypse that is coming.
Keywords

Park

Climate Change

Trees

Installation

Vegetation 

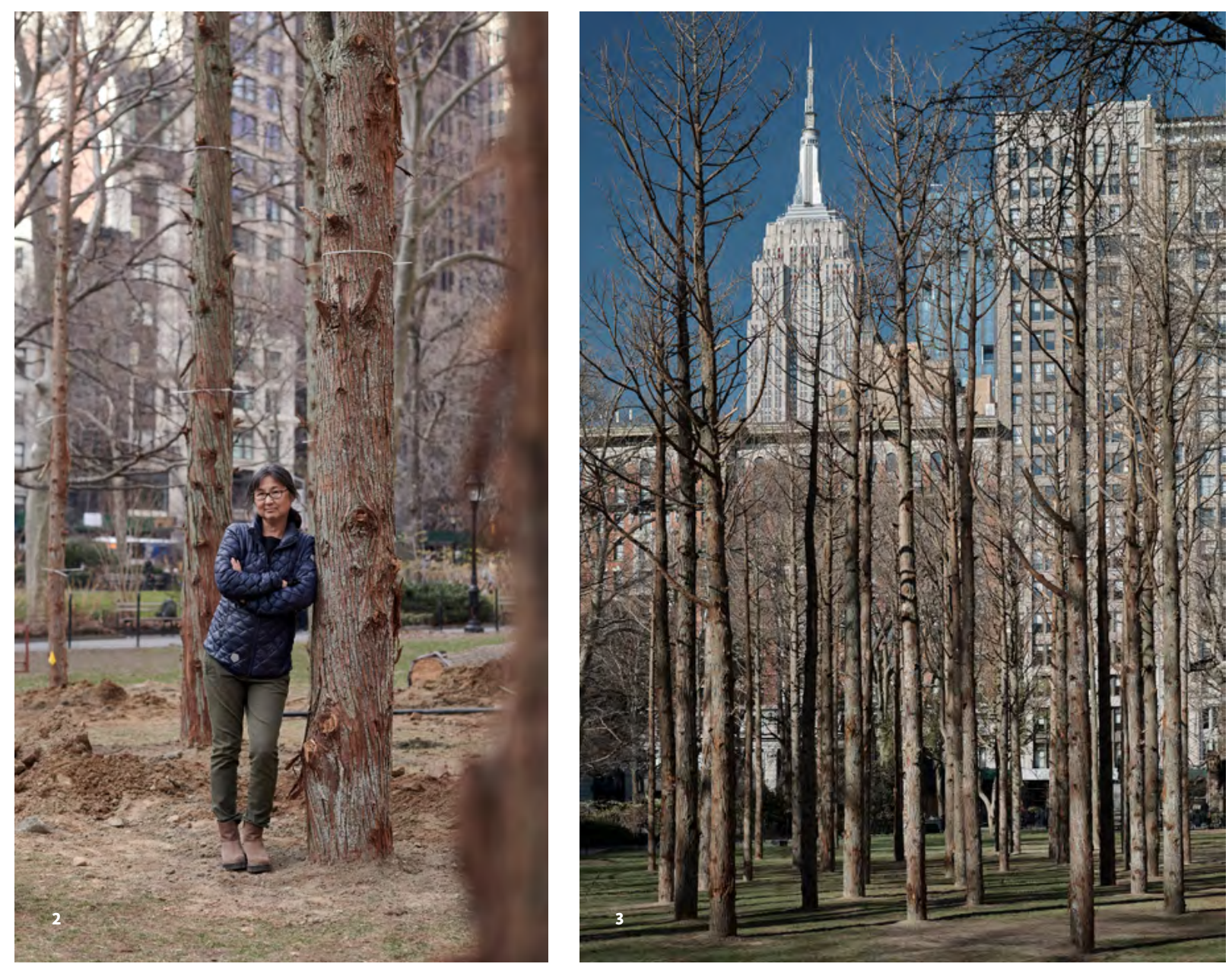

2 Maya Lin dentro del Bosquefantasma / Maya Lin within Ghost Forest, 2021.

(c) Andy Romer

Cortesía de / Courtesy

Maya Lin \& Madison

Square Park Conservancy

3-4 Maya Lin. Bosque fantasma / Ghost Forest, 2021.

(c) Andy Romer

Cortesía de / Courtesy

Maya Lin \& Madison

Square Park Conservancy
T hroughout the world, climate change is causing vast tracts of forested lands to die off. They are being called 'ghost forests'; they are being killed off by rising temperatures, extreme weather events that yield saltwater intrusion, forest fires, insects whose populations are thriving in these warmer temperatures, and trees that are more susceptible to beetles due to being overstressed from these rising temperatures.

In southwestern Colorado where my family and I live in the summer, these forests - killed off by beetles are all around us.

As I approached thinking about a sculptural installation for Madison Square Park, I knew I wanted to create something that would be intimately related to the Park itself, the trees, and the state of the earth.

Being more accustomed to making permanent large scale works out of earth and grass, I knew a different approach had to be taken - that I wanted to create something transient and temporal rather than creating a work that felt more like one of my permanent pieces. It is not a time frame I am familiar with in my outdoor installations. So much of my artwork focuses on species and habitat loss and the effects of climate change. 


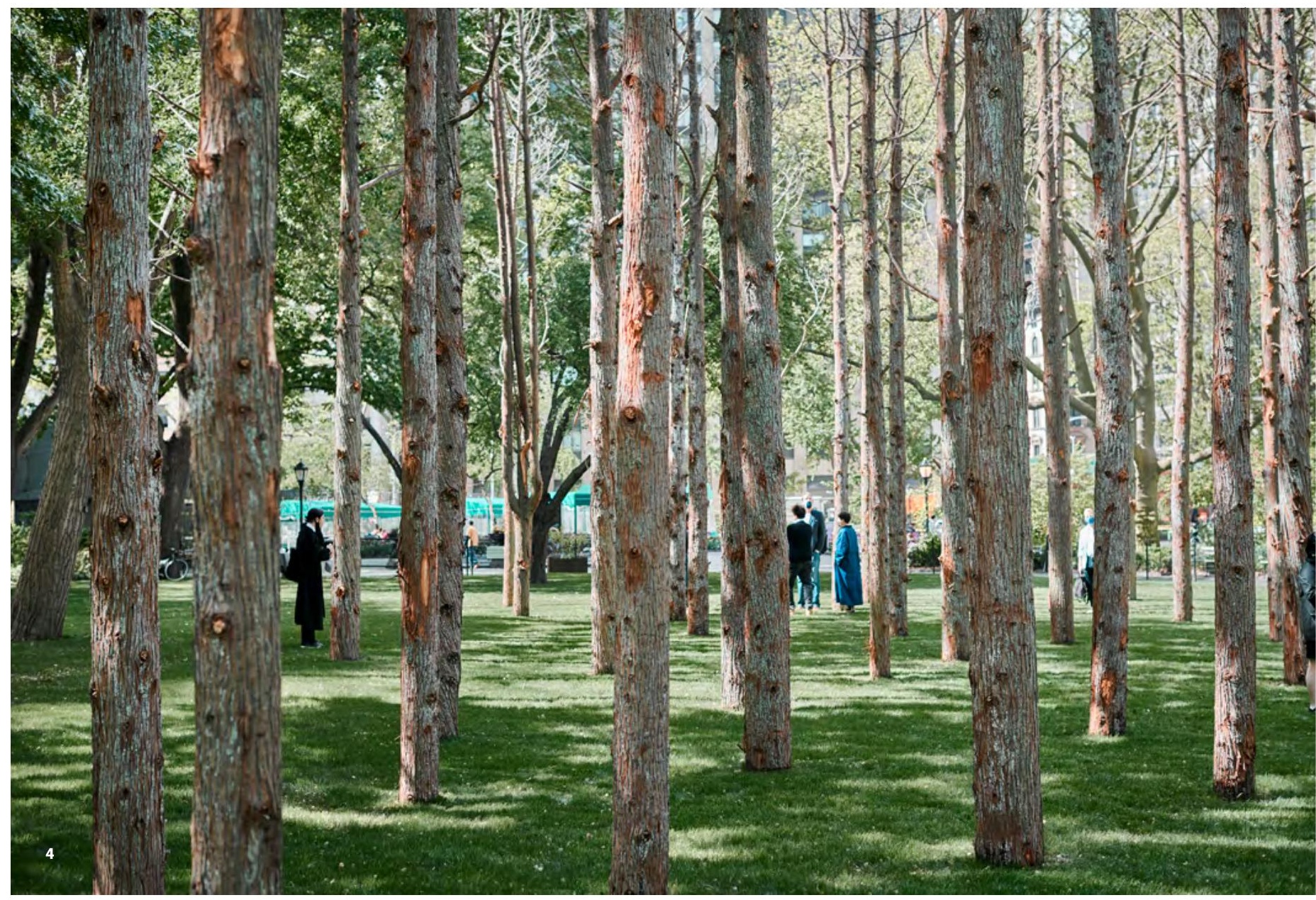

But also how, by protecting and restoring habitats, we can absorb climate change emission and take care of the species. I have established a non-profit foundation - What is Missing? - that has for the past decade focused as well on these issues.

I had first considered bringing a living willow walk to the Park - but the more I explored and thought about this, I could not stop looking at the ghost forest right outside my studio in Colorado which looks out onto national forest lands.

I wanted to bring a ghost forest to the heart of Manhattan - and to find trees that were as close to Manhattan as I possibly could find. All of us involved in the project were concerned not to bring in trees that had been killed by beetles lest we introduce a new species into the city that could potentially wreak havoc on Manhattan's trees, so we started to look for trees that were the victims of extreme weather events related to climate change.

We have been able to locate in the Pine Barrens large stands of dead Atlantic white cedars that have died off due to extreme weather events related to climate change, wind events, fire, sea-level rise, saltwater 


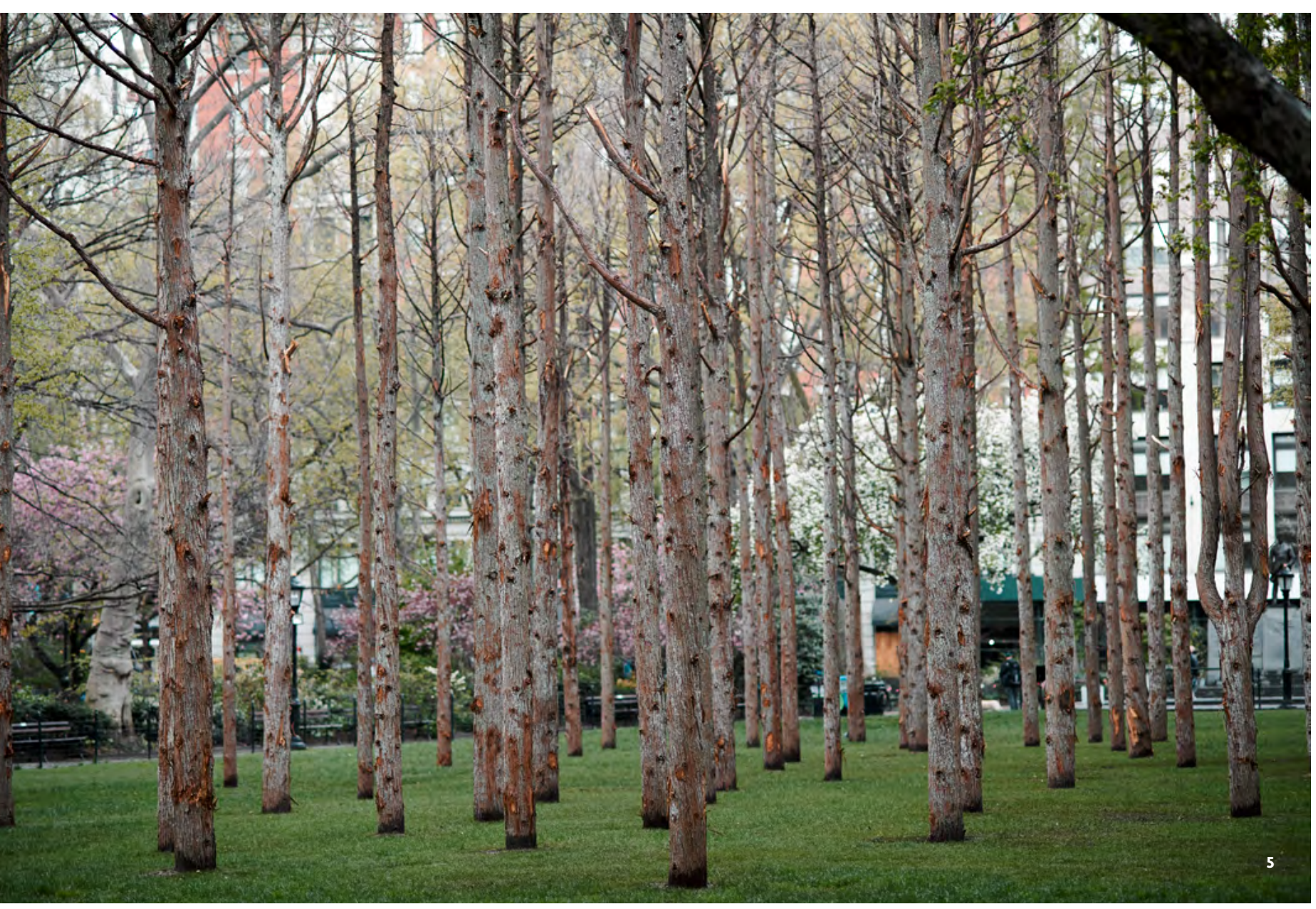

5-6 Maya Lin. Bosque fantasma / Ghost Forest

2021.

(c) Andy Romer

Cortesía de / Courtesy

Maya Lin \& Madison

Square Park Conservancy infiltration, and bad forestry practices. Atlantic white cedars that once were a dominant tree species along the Atlantic seaboard have been reduced to under ten percent of their original habitat. Foresters we are working with have located an area that was about to be cleared as part of a restoration project on private lands of just such a forest stand. The homeowner has chosen to clear the dead or compromised cedars to allow for the regeneration of the trees since cedars need open light to repopulate.

We have very little time left to change our climate change emission patterns and how we live within the natural world. I wanted to bring awareness to a die-off that is happening all over the world. I also feel that a potential solution is through nature-based practices - changing our forestry practices, reforming our agricultural and ranching practices and increasing our wetlands. These nature-based solutions can potentially offset and sequester over fifty percent of the world's emissions and would help protect and ensure that the Earth's biodiversity is increased and restored.

With the Conservancy we will be not just highlighting the ravages of climate change, but we will be showcasing 


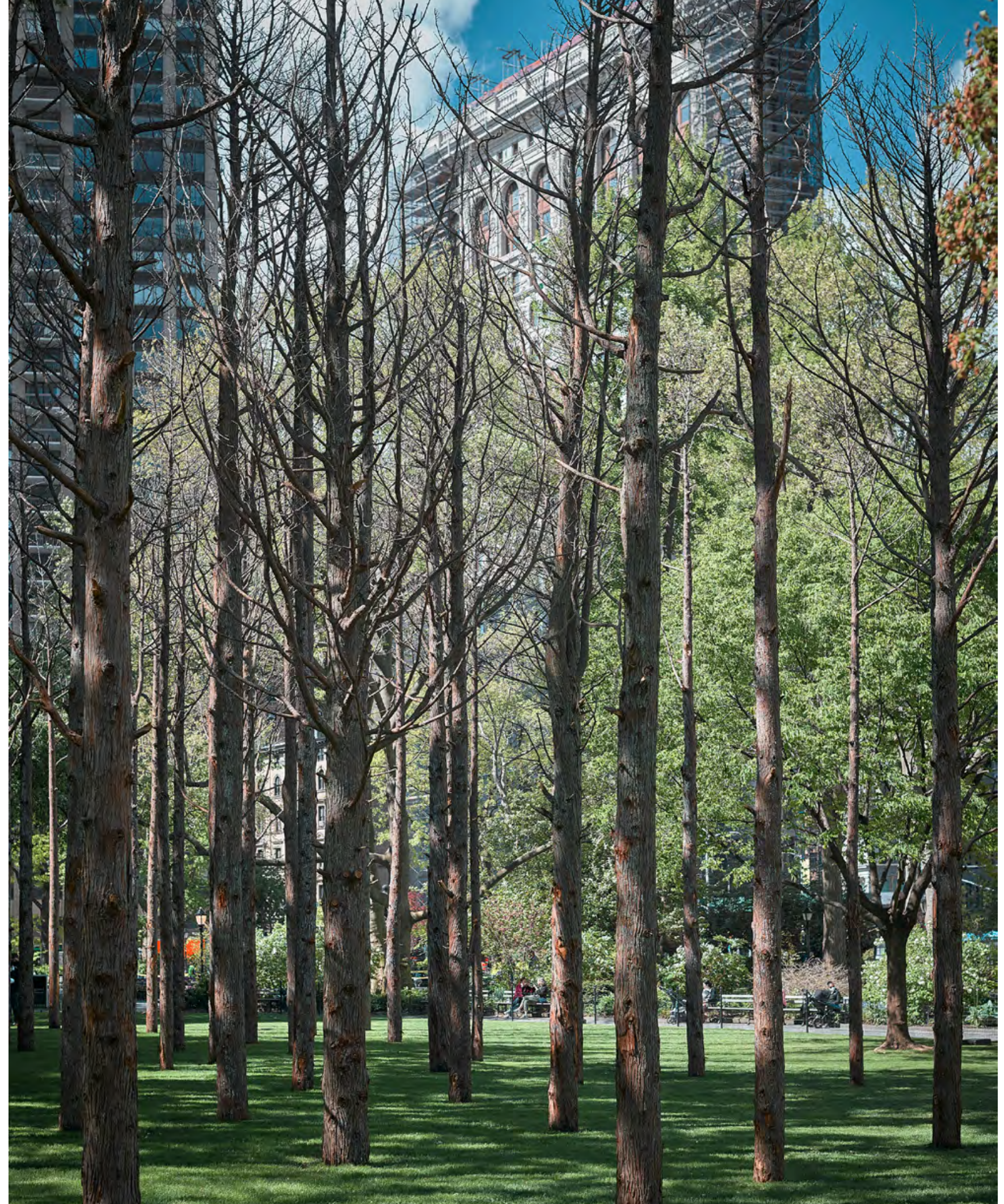



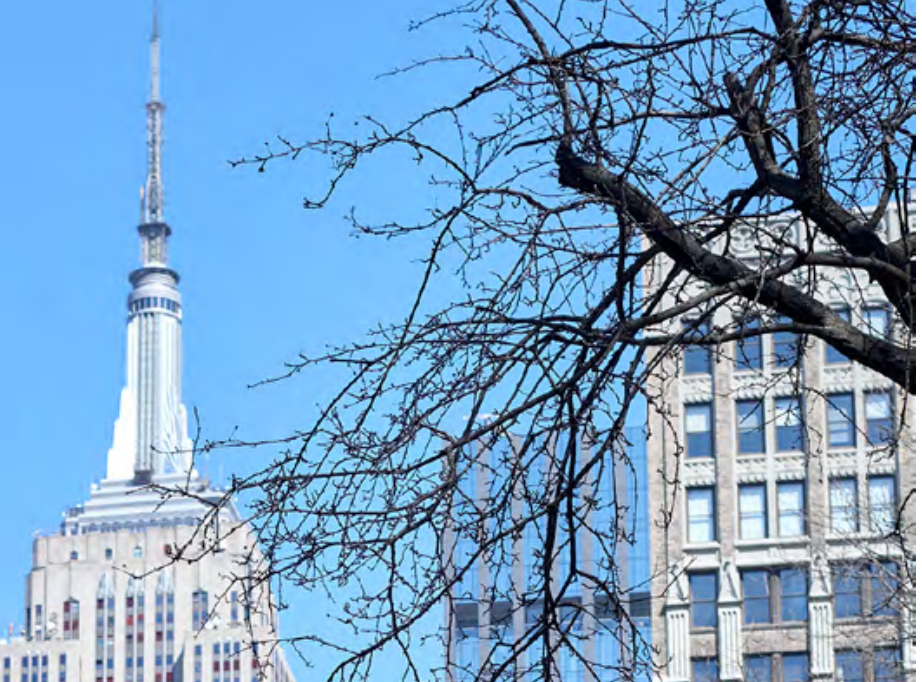

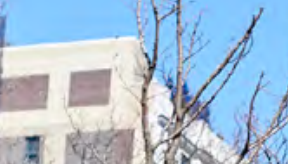

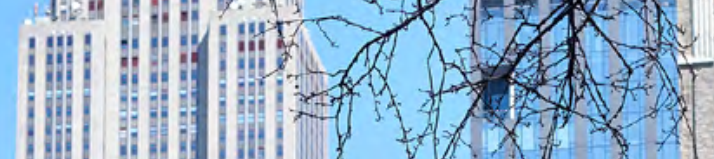

(2) (3)
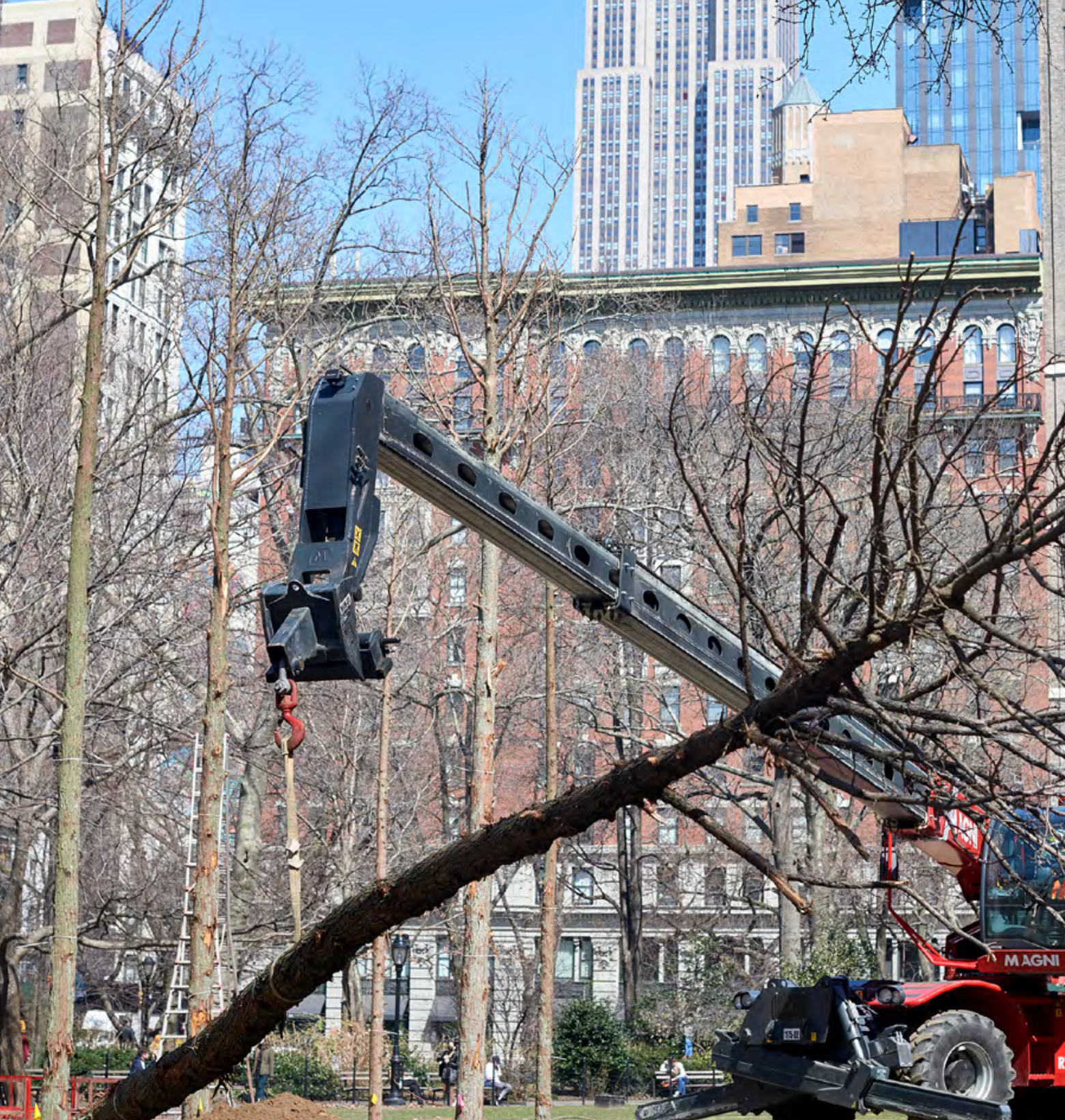

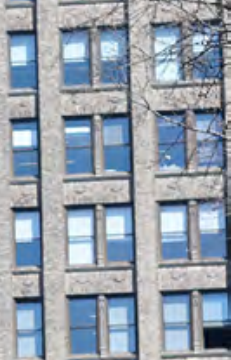

Non

(2)

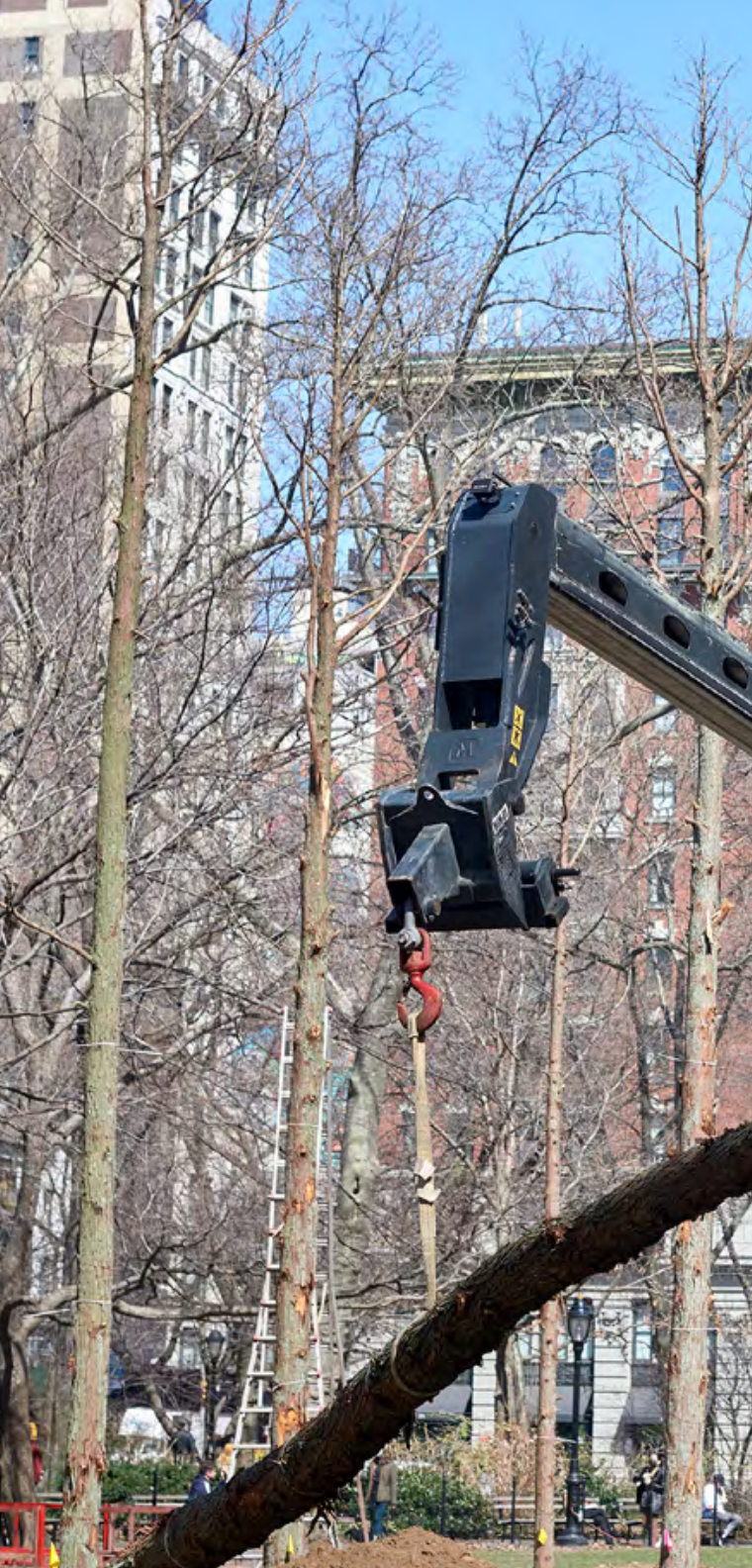

10 (1)

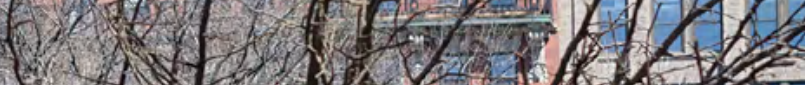

- $1 \frac{1}{1}$

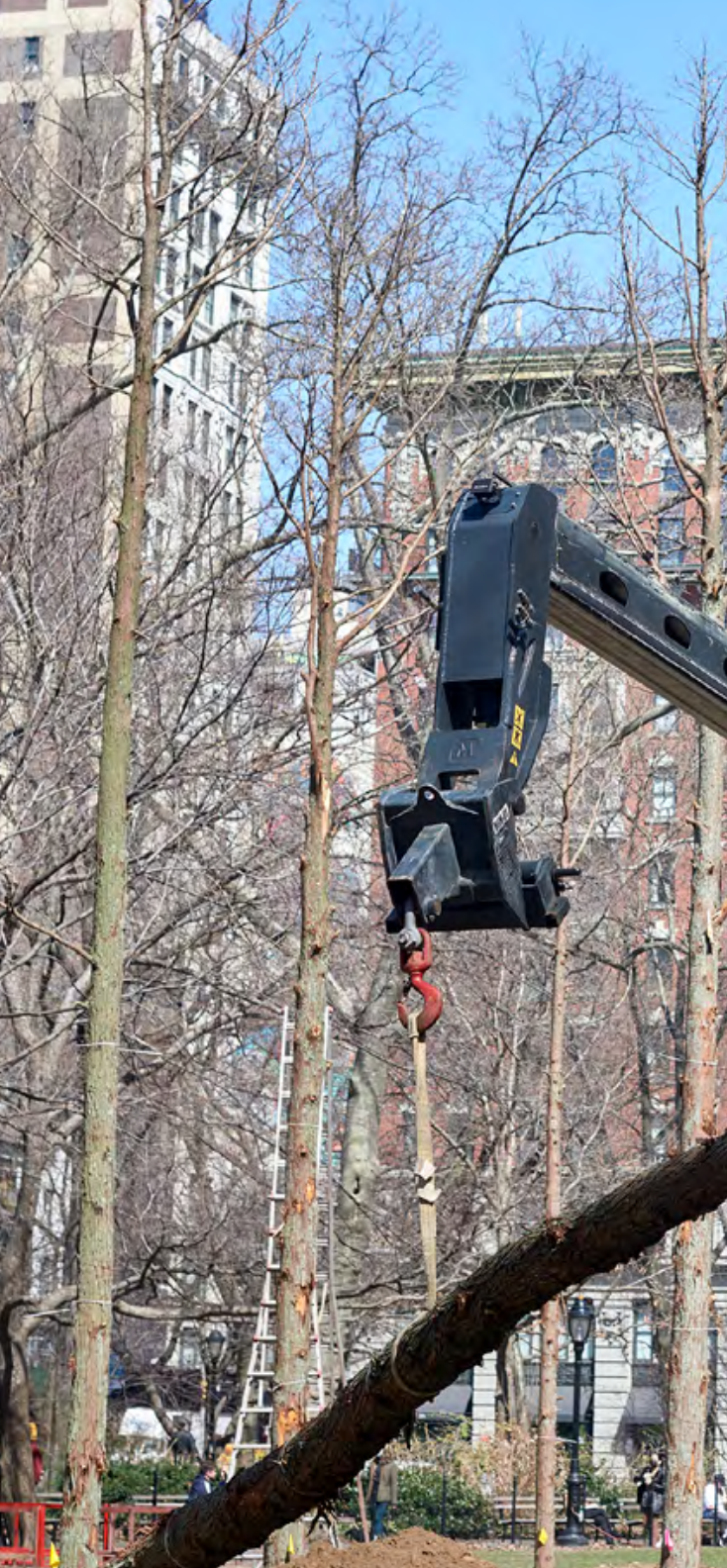

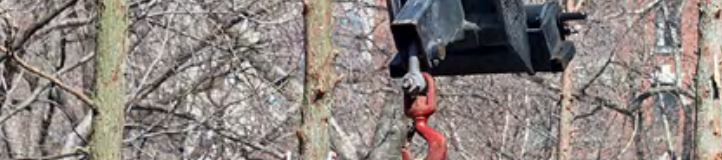

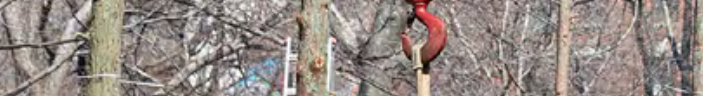

21

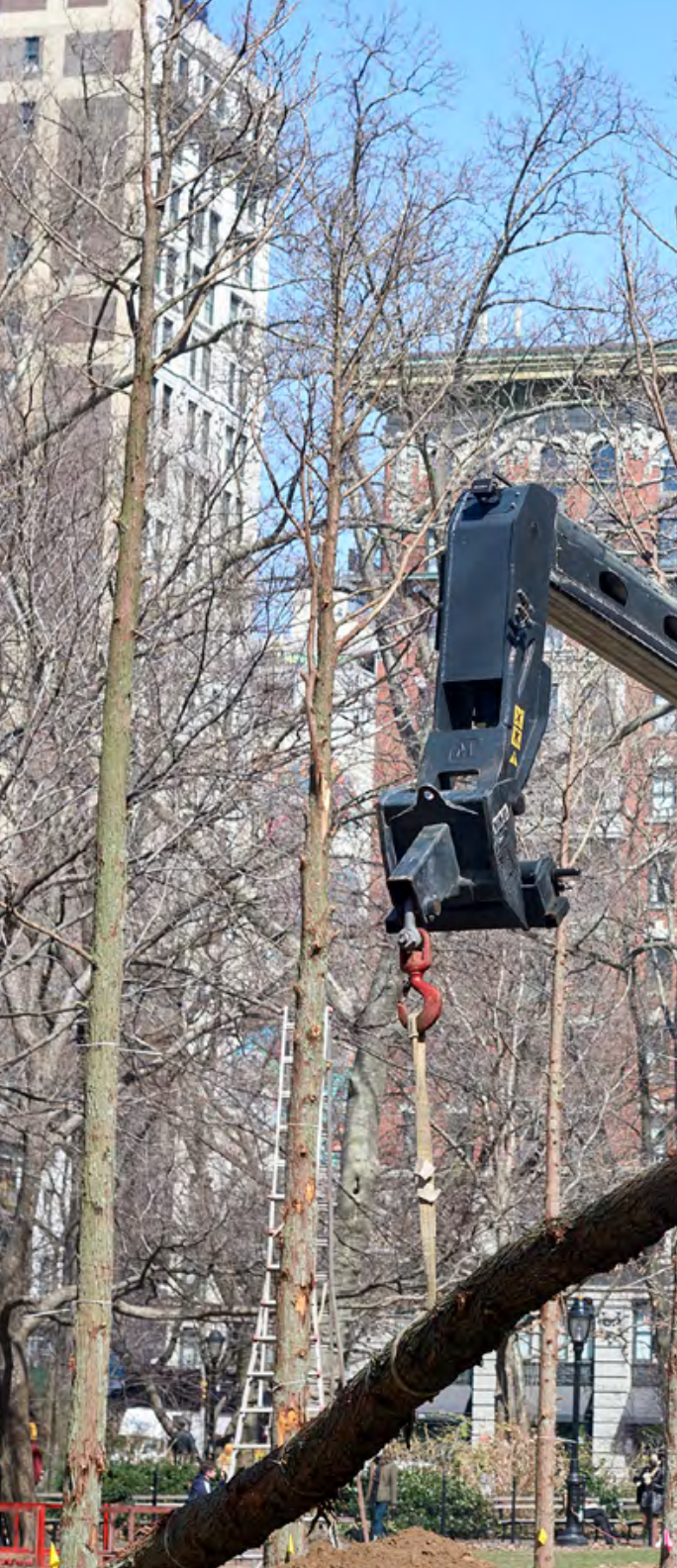

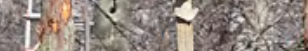

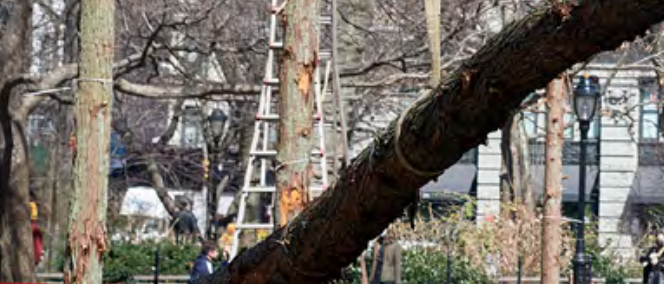
(5) (5) i) 7 तो 1)

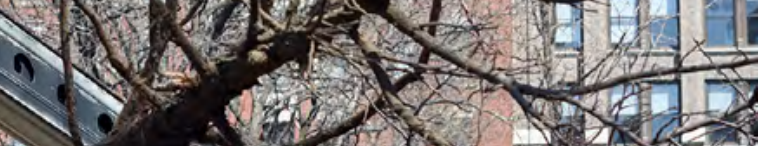

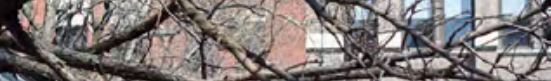

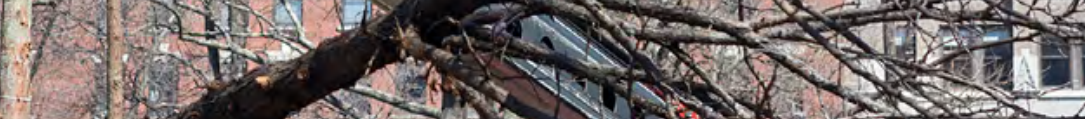



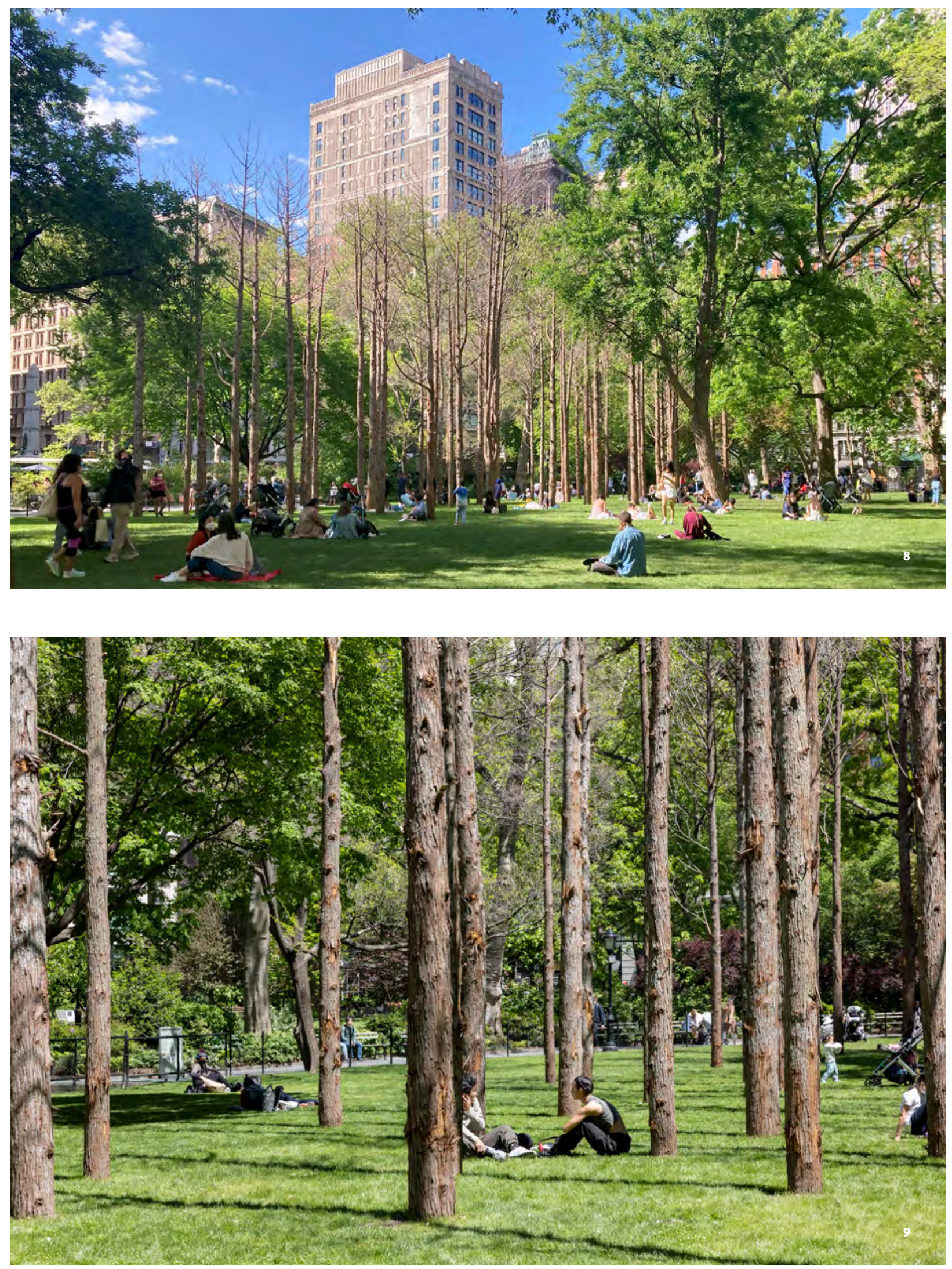

7 Maya Lin. Instalación del Bosque fantasma en proceso. / Installation of Ghost Forest in process. Madison Square Park, 2021. (c) Andy Romer

Cortesía de / Courtesy Maya Lin \& Madison Square Park Conservancy
8 Maya Lin. Bosque fantasma / Ghost Forest, 2021.

(c) Maya Lin Studio

Cortesía de / Courtesy Maya Lin \& Madison

Square Park Conservancy
9 Maya Lin. Bosque fantasma. 49 falsos cipreses blancos. / Ghost Forest. 49 Atlantic White cedars, 2021

(c) Rashmi Gill / Madison Square Park Conservancy Cortesía de / Courtesy Pace Gallery 


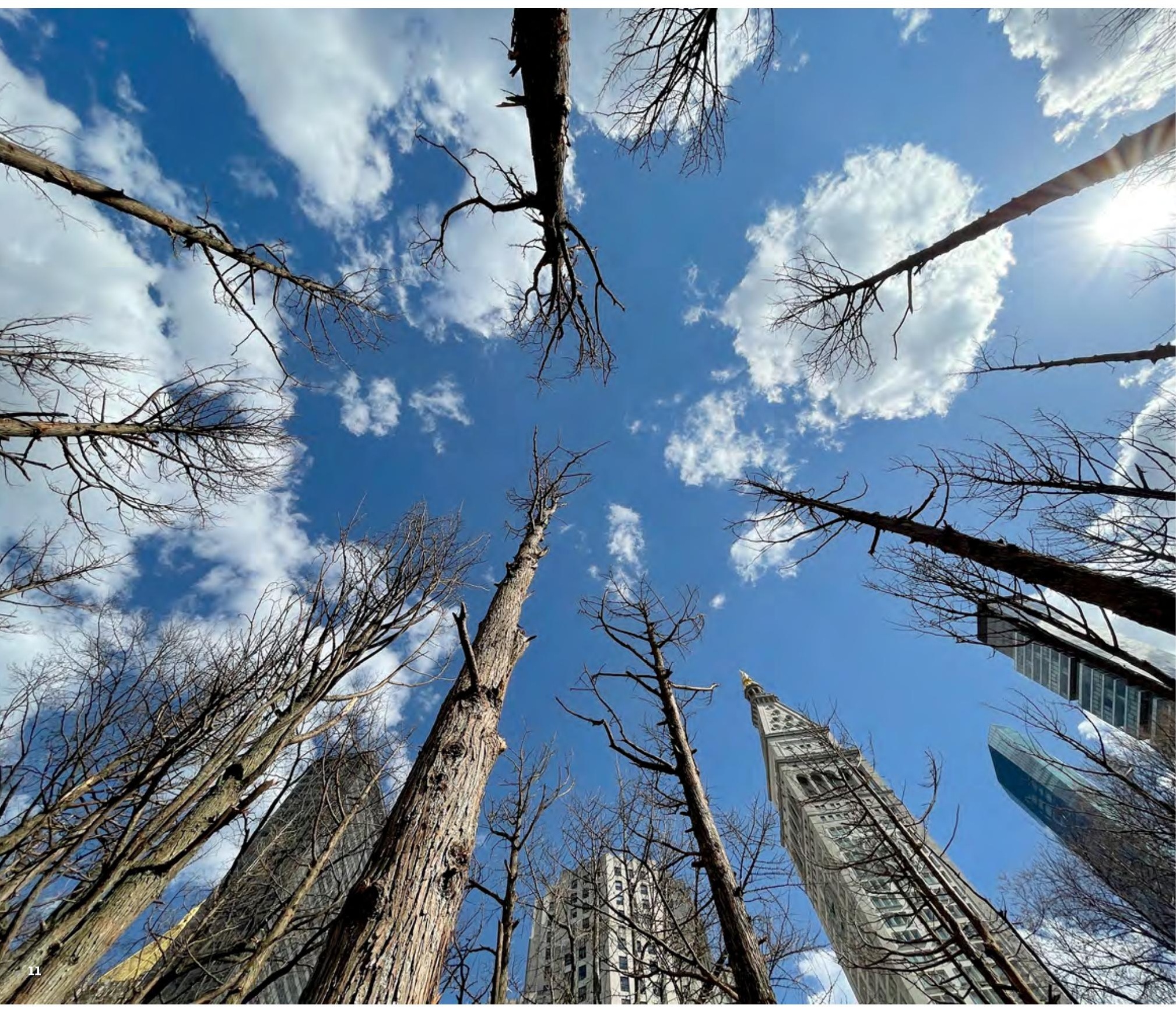

Maya Lin

Based in New York and Colorado, Lin holds degrees from Yale and Yale School of Architecture. She is internationally recognized for her wide-ranging practice that encompasses large-scale environmental installations, architectural projects, and memorials, as well as intimate studio artworks. A committed environmentalist, Lin has dedicated a significant part of her practice to exploring issues related to climate change, including the ongoing web-based project What is Missing? She has been the subject of numerous solo exhibitions worldwide, with works in the permanent collections of the National Gallery of Art, The Metropolitan Museum of Art, the Nelson-Atkins Museum of Art, among many others. In 2009, she was awarded the National Medal of Arts, and, in 2016, the Presidential Medal of Freedom. 